\title{
Mathematical modeling of a split-conditioner operation for evaluation of exergy efficiency of the R600A refrigerant application
}

\author{
Labay V., Dovbush O., Yaroslav V., Klymenko H. \\ Department of Heat, Gas Supply and Ventilation, \\ Institute of Construction and Environmental Engineering, \\ Lviv Polytechnic National University, \\ 12 S. Bandera Str., Lviv, 79013, Ukraine
}

(Received 26 October 2018)

\begin{abstract}
In the modern technologies related to energy transformation, namely in split-conditioners, an important place is occupied by apparatuses and processes, which energy perfection can be objectively evaluated only on the basis of analysis of their exergy efficiency. This allowed substantiating the actuality of the research task due to insufficient information on the effectiveness of the use of various refrigerants in split-conditioners. The author's innovation mathematical model for analysis of the work of one-step freon refrigerating machines, which are used in air split-conditioners, according to the exergetic method, is developed. The obtained exergetic output-input ratio (OIR) and losses of exergy in the separate elements on the example of air split-conditioner with nominal cooling capacity of $2800 \mathrm{~W}$ of "Daikin" firm in the standard external temperature conditions on the refrigerants R410A, R32 and proposed by the authors for the use in split-conditioners R600A refrigerant are obtained on this model. It was established that by the exergy efficiency, the R600A refrigerant is the most effective. The use of the R600A refrigerant when compared to R410A and R32 has shown the increase of the exergetic efficiency of the split-conditioner in $12.4 \%$ and $8.7 \%$, respectively. The losses of exergy having been established in all elements of refrigerating machine of the air split-conditioner indicate that the air split-conditioner parts should be improved to reduce the losses of exergy in them and to increase its exergetic OIR in general.
\end{abstract}

Keywords: air split-conditioner, exergetic balance, exergetic output-input ratio (OIR), losses of exergy, refrigerant.

2000 MSC: $80 \mathrm{~A} 10,80 \mathrm{~A} 20$

UDC: $697.94 .(075)$

DOI: $10.23939 / \mathrm{mmc} 2018.02 .169$

\section{Introduction}

Currently for Ukraine the problem of saving energy resources is particularly relevant in conditions of market economy, limited resources of primary energy commodities - oil and gas.

Now in the housing sector settlements of Ukraine there is a process of redistribution of the share of consumption of thermal and electric energy, due to the constant reduction of thermal capacity of traditional heating systems, a significant growth of tariffs for heat energy and gas fuels and higher household consumption of electric energy to create a comfortable indoor climate in warm and cold periods of the year for which widely used of the air conditioning system, in particular air split-conditioners. The last years in domestic refrigeration equipment refrigerant R600A is widely used, which led to its energy saving while its exploitation in comparison with other refrigerants. At the same time using air split-conditioners, this refrigerant has not found its application.

In recent decades both abroad and in Ukraine with the aim of saving energy resources, fundamental research in a number of industries and technologies from the standpoint of exergetic methodology have been conducted [1-13]. 
Flows of energy and exergy always coexist. They can be equal to each other, if we are talking about fluxes of mechanical or electric energy, and be very different in flows of heat. Exergy not only quantifies the energy of any kind, but also allows estimate its quality. It defines convergence, suitability of energy for its technical use in any conditions.

Since exergy is the only measure of work ability, that is, suitability of energy resources for use, it enables to objectively evaluate the energy resources of any kind. Consequently, exergy is some universal measure of the suitability of energy resources. And exergetic balance, on the basis of which the volume of energy resources is set, indicates the possibility of increasing the OIR of the process.

In some leading European countries and in USA exergy analysis has been introduced as a mandatory component in development of projects and plans of modernization of manufacturing.

So, to convince the energy efficiency of application of refrigerant R600A in split-conditioners we have conducted analytical researches on the developed mathematical model of air split-conditioner operation under the exergy method for one of conditioners of the firm "Daikin". Similar results could be obtained on any other air split-conditioner, of any other firm and any other refrigerant. And this indicates to the actuality of this research.

\section{Analysis of literature data and problem decision}

Successful application of the exergy method of analysis of different technical systems, in particular of refrigerating machine of air split-conditioners, have been grounded in the works of R.K. Clausius, John V. Gibbs, G. Gouy, A. Stodola, J. Szargut, R. Petela and V. M. Brodyansky for their technical and economic optimization [1-10]. Currently, costs estimates cannot be the only measure of effectiveness of energy equipment that use energy. Exergy is independent from the fluctuations of prices.

Modern air split-conditioners, which are used to create a suitable microclimate in small rooms, have achieved some definite technical improvement. As it is known, energy efficiency of refrigerating machines of these air split-conditioners depends on parameters of both external and internal temperature conditions of their work and type of refrigerant [2]. Therefore, for further improving of efficiency of work of refrigerating machines of air split-conditioners a detailed analysis of their functioning using different cooling agents, in particular R600A need to be hold on.

For this purpose, based on the work [2], the innovative mathematical model of exergy analysis of the operation of refrigerating machines of air split-conditioners has been developed by the authors, adapted for different refrigerants and manufacturers. This mathematical model makes it possible to carry out exergy investigations of the refrigerating machine as a whole one and of its individual parts, for obtaining full information about the processes of energy transformation that have place in such systems [11-13]. The result of the analysis is finding the exergy OIR of process in overall and the exergy losses in individual elements of the refrigerating machine of air split-conditioner with the aim of its optimization.

So, based on analysis of available literature data, decreasing the energy costs that used by air split-conditioners can be the most complete achieved on the basis of exergy analysis, which takes into account not only the quantity but also the quality of spent energy [11-13].

\section{Purpose and tasks of the investigation}

The purpose of this work is to determine the exergetic OIR and exergy losses in separate elements of air split-conditioner of firm "Daikin" on the two-component refrigeration agent R410A and one-component R32 and R600A (isobutane), which is proposed by the authors for using in air split-conditioners R600A.

To achieve this purpose the following basic tasks have been formulated:

- to set the exergetic OIR on the example of air split-conditioner with nominal cooling capacity $2800 \mathrm{~W}$ of firm "Daikin" at standard external temperature conditions on refrigerants R410A, R32 and R600A;

- to determine the exergy losses in separate elements of air split-conditioner, for example, of firm "Daikin" with standard cooling capacity of $2800 \mathrm{~W}$ on refrigerants R410A, R32 and R600A.

Mathematical Modeling and Computing, Vol. 5, No. 2, pp. 169-177 (2018) 


\section{Methods, materials and results of researches}

In this work the object of the research are thermodynamic processes in refrigerating machines of split-conditioners for cooling air, which are investigated on one-stage steam-compressor refrigerating machine (without effective cooling of the compressor), that used for air split-conditioners, the scheme of which is shown in Fig. $1 a$.
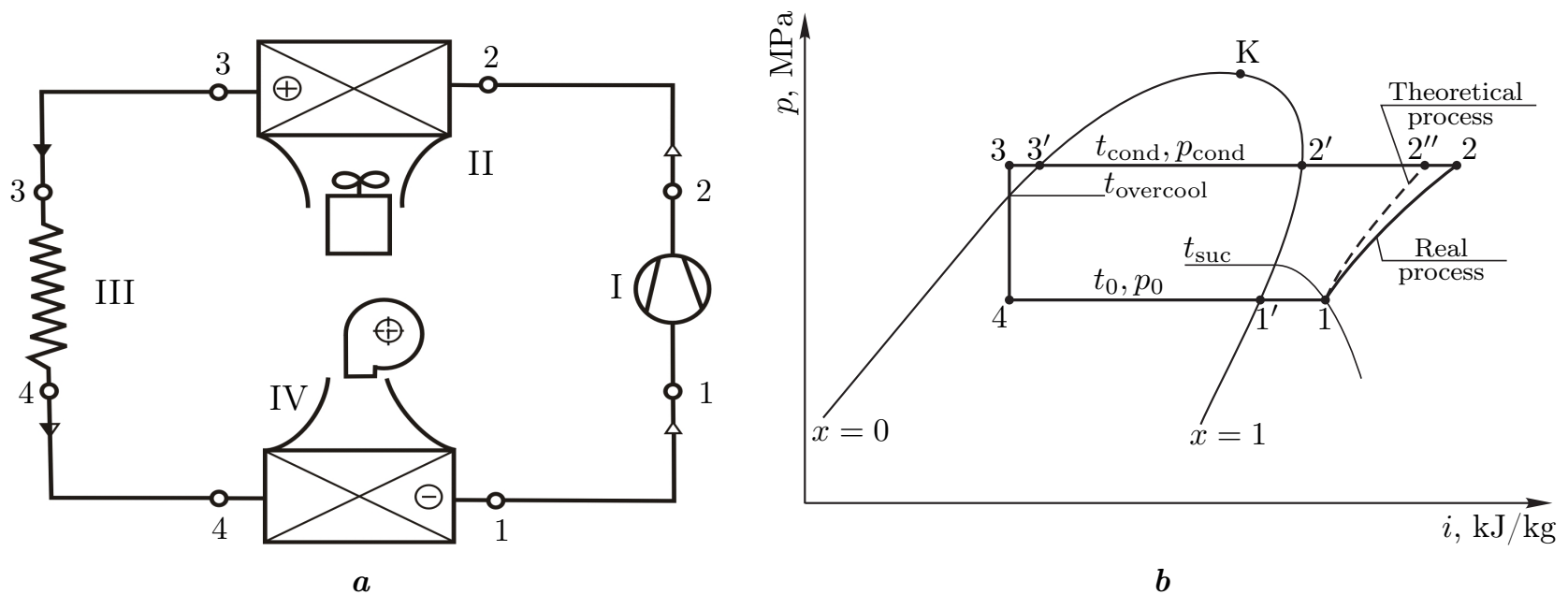

Fig. 1. Scheme of refrigerating machine of air split-conditioner $(\boldsymbol{a})$ and construction of the processes of work on $(p, i)$-diagram $(\boldsymbol{b})$ : I is compressor; II is condenser; III is capillary tube; IV is evaporator; 1, 2, 3, 4 are characteristic points of the thermodynamic cycle.

The work of this refrigerating machine is as follows. Heat from the internal (recirculation) air of a room is been supplying to the working refrigerating agent (RA) in the evaporator IV. As a result of heat supplying the working refrigerant boils in the evaporator IV under the constant pressure of evaporation $p_{0}=p_{\mathrm{ev}}$ and the evaporation temperature $t_{0}=t_{\mathrm{ev}}$, and also overheats under pressure $p_{\mathrm{ev}}$ from temperature $t_{\mathrm{ev}}$ to suction temperature $t_{\mathrm{suc}}$. After that, the overheated steam from the evaporator IV is sucked by compressor I.

In compressor I, the overheated steam of the working refrigerant is compressed from the evaporation pressure $p_{\mathrm{ev}}$ to the condensation pressure $p_{\text {cond }}$ as the temperature rises from $t_{\text {suc }}$ to $t_{2}$.

Due to friction, irreversible heat transfer and non-adiabatic, the real compression process $1-2$ in a compressor I does not coincide with isentropic compression $1-2^{\prime \prime}$.

From compressor I, overheated steam enters the condenser II, where because of heat transfer to outside air (environment), there is a process of cooling of the working refrigerant from the temperature $t_{2}$ to the condensation temperature $t_{\text {cond }}$ process of condensation of the steam of the RA along the constant condensation pressure $p_{\text {cond }}$ and the condensation temperature $t_{\text {cond }}$ and process of overcooling of liquid RA under pressure $p_{\text {cond }}$ from temperature $t_{\text {cond }}$ to overcooling temperature $t_{\text {overcool }}$.

After the condenser II, the liquid refrigerant passes through the capillary tube (throttler) III, where, due to the throttling of the working refrigerant, the pressure falls from $p_{\text {cond }}$ to $p_{\text {ev }}$ and the temperature decreases from $t_{\text {cond }}$ to $t_{\mathrm{ev}}$. During this the working RA partially evaporates $(\sim 20 \%)$. After the capillary tube III, the working RA enters again the evaporator IV and the refrigeration cycle repeats again.

Technical characteristics of such refrigerating machines, as usual, are pointed at a standard external temperature mode, which is determined by: standard temperature of surrounding environment (outside air) $t_{\mathrm{H} 1}=35^{\circ} \mathrm{C}$ (at relative humidity $\varphi_{\mathrm{H} 1}=40 \%$ (accordingly, moisture content $d_{\mathrm{H} 1}=13.8 \mathrm{~g} / \mathrm{kg}$ and specific enthalpy $I_{\mathrm{H} 1}=70.6 \mathrm{~kJ} / \mathrm{kg}$ ) (here the index " $\mathrm{H}$ " is heat) and standard temperature of the conditioned internal (recirculation) air in a room $t_{\mathrm{C} 1}=27^{\circ} \mathrm{C}$, according to temperature of surrounding environment (at relative humidity $\varphi_{\mathrm{C} 1}=46 \%$ ) (accordingly, moisture content $d_{C 1}=10.1 \mathrm{~g} / \mathrm{kg}$ and specific enthalpy $I_{\mathrm{C} 1}=52.8 \mathrm{~kJ} / \mathrm{kg}$ ) (here the index "C" is cool). 
For calculations of the standard cooling process depicted on $(p, i)$-diagram at steady-state thermal condition of refrigerating machine, when in the unit of time through each of its element (compressor, condenser, capillary tube and evaporator) a constant quantity of the refrigerant is circulating. Given values for calculating are: cooling capacity $Q_{\mathrm{C}}, W$, consumable power $N_{\mathrm{in}}, W$, amount of condensate on the evaporator $W_{\text {cond }}, 1 / \mathrm{h}$, and internal temperature regime of the refrigerating machine of air split-conditioner, which in the occasion of work in a one-component RA, is characterized by four temperatures $t_{\mathrm{ev}}, t_{\mathrm{suc}}, t_{\mathrm{cond}}, t_{\mathrm{overcool}}$, which are determined by external temperature regime and air flows on the evaporator $L_{\mathrm{ev}}, \mathrm{m}^{3} / \mathrm{h}$, and the condenser $L_{\text {cond }}, \mathrm{m}^{3} / \mathrm{h}$.

Construction on $(p, i)$-diagram of the process of work of the refrigerating machine of air splitconditioner is shown in Fig. $1 b$.

Note the processes that characterize the cut-offs that are obtained on the ( $p, i)$-diagram (Fig. $1 b)$ :

- $1-2^{\prime \prime}$ is theoretical (adiabatic $s_{1}=$ const) compression in the compressor of dry overheated steam of the RA from the evaporation pressure $p_{\mathrm{ev}}$ to the condensation pressure $p_{\text {cond }}$.

- $1-2$ is real (polytropic) compression in the compressor of dry overheated steam of the RA from the evaporation pressure $p_{\mathrm{ev}}$ to the condensation pressure $p_{\text {cond }}$.

- $2-2^{\prime}$ is isobaric cooling ( $p_{\text {cond }}=$ const) of overheated steam of the RA in the condenser from the temperature $t_{2}$ to the temperature of condensation (saturation) $t_{\text {cond }}$ due to removal of heat by cooling external air (environment).

- $2^{\prime}-3^{\prime}$ is isobaric-isothermal $\left(p_{\text {cond }}=\right.$ const, $t_{\text {cond }}=$ const $)$ condensation of steam of the RA in the condenser due to removal of heat by cooling external air.

- $3^{\prime}-3$ is isobaric overcooling $\left(p_{\text {cond }}=\right.$ const $)$ of the liquid refrigerant in the condenser from the condensation temperature $t_{\text {cond }}$ to the overcooling temperature $t_{\text {overcool }}$ due to removal of heat by cooling external air.

- $3-4$ is isoenthalpic $\left(i_{3}=\right.$ const $)$ throttling of the liquid refrigerant in the capillary tube with a decrease in pressure from $p_{\text {cond }}$ to $p_{\text {ev }}$.

- $4-1^{\prime}$ is isobaric-isothermal ( $p_{e v}=$ const, $t_{\mathrm{ev}}=$ const) evaporation of the liquid RA in the evaporator due to the heat supply from the cooled internal (recirculation) air of the room.

- $1^{\prime}-1$ is isobaric $\left(p_{e v}=\right.$ const) overheating of the RA steam in the evaporator from the evaporation temperature $t_{\mathrm{ev}}$ to the suction temperature $t_{\mathrm{suc}}$ due to the heat supply from the cooled indoor air of the room.

Overcooling of the refrigerant (line $3^{\prime}-3$ ) compensates losses during throttling and increases cooling capacity of the air conditioner. Some overheating of vapor of the RA before suction in a compressor (line $1^{\prime}-1$ ) provides the "dry" course of the compressor.

Then find the parameters of the working refrigeration agent in the characteristic points of the scheme of air conditioner refrigerating machine or by using the thermodynamic $(p, i)$-diagram of RA or by using its tables $[14,15]$ or according to the formulas obtained by the authors on the basis of the tables for the corresponding RA and valid in the temperature range $0 \ldots 50^{\circ} \mathrm{C}$.

For calculating the exergetic OIR and analysis of work of refrigerating machine of air splitconditioner, the following output data are necessary to have:

- standard cooling capacity of air split-conditioner $Q_{\mathrm{C}}^{\mathrm{st}}, \mathrm{W}$;

- the internal air temperature at the enter $t_{\mathrm{C} 1}=27^{\circ} \mathrm{C}$ in the evaporator and the inflow one at the exit $t_{\mathrm{C} 2}$ from it;

- the temperature of the outside air at the enter $t_{\mathrm{H} 1}=35^{\circ} \mathrm{C}$ and at the exit $t_{\mathrm{H} 2}$ from the condenser;

- thermodynamic properties of RA-refrigerants R410A, R32 and R600A;

- scheme of the refrigeration unit (Fig. 1a).

Initially, the evaporation and condensation temperatures were calculated at standard external temperature conditions for the evaporator, when the internal air of room which is cooled in the evaporator of the air split-conditioner has an initial temperature $t_{C 1}=27^{\circ} \mathrm{C}$ and for a condenser, when the external air by which the air split-conditioner condenser is cooled by has an initial temperature of 
$t_{\mathrm{H} 1}=35^{\circ} \mathrm{C}$, and the temperature of the suction of a steam of the refrigerant in the compressor and the overcooling of the liquid refrigerant in the condenser. Then the process of work of the refrigerating machine without cooling the compressor in the thermodynamic corresponding $(p, i)$-diagram (Fig. $1 b$ ) has been built. In the characteristic points of the scheme by the diagram or by tables or by formulas, the parameters of the refrigerant have been finding $[14,15]$.

By thermodynamic $(p, i)$-diagram, the heat consumption per unit cost of the working refrigeration agent in separate units of the refrigerating machine of the air split-conditioner have been finding.

Specific internal indicator work of the compressor of the air split-conditioner is:

$$
l_{i}=i_{2}-i_{1}, \mathrm{~kJ} / \mathrm{kg},
$$

where $i_{1}$ and $i_{2}$ are the specific enthalpy at the corresponding points of the refrigeration cycle, $\mathrm{kJ} / \mathrm{kg}$.

Then find the cooling ratio of the installation of the air split-conditioner according to the formula:

$$
\varepsilon=\eta_{\mathrm{em}} q_{0} / l_{i}
$$

where $\eta_{\mathrm{em}}$ is the electromechanical OIR of the compressor $\left(\eta_{\mathrm{em}}=0.9\right) ; q_{0}=i_{1}-i_{4}, \mathrm{~kJ} / \mathrm{kg}$ is specific heat consumption in the evaporator per unit cost of the refrigerant.

The exergetic OIR of the refrigerating machine of the air split-conditioner have founded by the formula:

$$
\eta_{\mathrm{e}}=E_{\mathrm{C}} \cdot \varepsilon
$$

where $E_{\mathrm{C}}=T_{e n v} / \bar{T}_{\mathrm{C}}-1$ is the specific consumption of electric energy (exergy) in the ideal cycle, that is attributed to the unit of heat been brought to the heat receiver (evaporator) with the average temperature $\bar{T}_{\mathrm{C}}, \mathrm{K} ; T_{\text {env }}$ is environmental temperature, $\mathrm{K}$.

The value of exergy of the refrigerant in the characteristic points of the process have determined by the formula:

$$
e=i-i_{\mathrm{env}}-T_{\mathrm{env}}\left(s-s_{\mathrm{env}}\right), \mathrm{kJ} / \mathrm{kg},
$$

where $i$ is the value of the specific enthalpy of the refrigerant in the characteristic points of the process, $\mathrm{kJ} / \mathrm{kg} ; i_{\mathrm{env}}$ is the value of the specific enthalpy of the refrigerant in the state $T_{\text {env }}, p_{\text {env }}$ (temperature and pressure of the environment), which is in equilibrium with the environment, $\mathrm{kJ} / \mathrm{kg}$; $s$ and $s_{\text {env }}$ are corresponding values of the refrigerant entropy, $\mathrm{kJ} /(\mathrm{kg} \cdot \mathrm{K})$, which have been determined by thermodynamic tables or diagrams or formulas [14,15].

Then find the specific amount of exergy which is inputed into the refrigerating machine of the air split-conditioner in the form of electric energy that is brought to the electric motor of compressor, using the formula:

$$
e_{\text {in }}=N_{\text {in }} \cdot 10^{-3} / G, \mathrm{~kJ} / \mathrm{kg},
$$

where $N_{\text {in }}$ is the power consumed by the electric motor of the compressor, W; $G=Q_{\mathrm{C}} \cdot 10^{-3} / q_{0}$ is the quantity of circulating refrigeration agent in the contour of refrigerating machine, $\mathrm{kg} / \mathrm{s}$.

The losses of exergy in some apparats of the refrigerating machine of the air split-conditioner is:

$$
d=e_{\mathrm{beg}}-e_{\mathrm{end}}, \mathrm{kJ} / \mathrm{kg}
$$

or as a percentage of the exergy that is entered into the refrigerating machine:

$$
D=\left(e_{\mathrm{beg}}-e_{\mathrm{end}}\right) \cdot 100 / e_{\mathrm{in}}, \%
$$

where $e_{\mathrm{beg}}$ and $e_{\mathrm{end}}$ are value of the specific exergy of the refrigerant in the beginning and at the end of the process in a separate apparatus of the refrigerating machine of air split-conditioner, $\mathrm{kJ} / \mathrm{kg}$.

The exegetic balance of the one-stage steam-compressor refrigerating machine (without effective cooling of compressor) of the air split-conditioner for $1 \mathrm{~kg} / \mathrm{s}$ of the flow of a circulating working refrigerant 
has the form [11-13]:

$$
e_{\text {in }}=e_{\text {out }}+\Sigma d, \mathrm{~kJ} / \mathrm{kg}
$$

or as a percentage of $e_{\text {in }}$

$$
E_{\text {in }}=E_{\text {out }}+\Sigma D, \%,
$$

where $e_{\text {in }}$ is the quantity of the specific exergy that enters into refrigerating machine of conditioner, $\mathrm{kJ} / \mathrm{kg} ; e_{\text {out }}$ is the quantity of the specific exergy, which comes out from the refrigerating machine of the conditioner, $\mathrm{kJ} / \mathrm{kg} ; \Sigma d$ are total losses of specific exergy in all apparatuses of the refrigerating machine of the conditioner, $\mathrm{kJ} / \mathrm{kg} ; E_{\mathrm{in}}, E_{\text {out }}, \Sigma D$ is respectively, exergy of the refrigerating machine of air split-conditioner, which is spent on maintaining the process of its work; the increase of exergy of air in air-conditioned premises; total losses of exergy in all apparatuses of the refrigerating machine of the air conditioner as a percentage (\%) of the exergy $e_{\text {in }}$, which is included in the refrigerating machine.

Losses of exergy in the refrigerating machine of the air conditioner consists of losses of exergy in the compressor, the condenser, the capillary tube (throttle) and the losses of exergy due to the irreversible heat transfer in the evaporator, i.e.

$$
\begin{aligned}
\Sigma d & =d_{\text {compr }}+d_{\text {cond }}+d_{\mathrm{thr}}+d_{\mathrm{ev}}^{\text {irrev.h.tr }}, \mathrm{kJ} / \mathrm{kg} ; \\
\Sigma D & =D_{\text {compr }}+D_{\text {cond }}+D_{\mathrm{thr}}+D_{\mathrm{ev}}^{\text {irrev.h.tr }}, \%,
\end{aligned}
$$

where $D_{\text {compr }}, D_{\text {cond }}, D_{\mathrm{thr}}, D_{\mathrm{ev}}^{\text {irrev.h.tr }}$ are respectively, losses of exergy in the compressor, the condenser, the capillary tube and the evaporator, $\%$.

The exergetic balance of this refrigerating machine of the air split-conditioner based on its principal scheme (Fig. 1a).

Obviously, the perfection of the refrigerating machine of the air split-conditioner and its elements is that higher, the higher the exergetic OIR is, which was also determined from the exergetic balance, namely $[1,2,11-13]$ :

$$
\eta_{\mathrm{e}}=E_{\text {out }} / E_{\text {in }}
$$

Calculation of the exergetic OIR of the refrigerating machine of air split-conditioner creates conditions for solving the issue of saving fuel and energy resources [1,2,11-13].

Consequently, the exergetic OIR of the refrigerating machine of air split-conditioner also have been calculated by the formula (12), in which the numerator is a useful exergetic effect, and the denominator is the cost of exergy.

We have calculated the exergetic OIR of the one-stage refrigerating machine of air split-conditioner of firm "Daikin" with nominal cooling capacity $Q_{\mathrm{C}}^{\text {st }}=2800 \mathrm{~W}$ at standard temperature conditions on refrigerants R410A, R32 and R600A. For the calculation were accepted:

- overcooling of the liquid refrigerant in the condenser $\Delta t_{\text {overcool }}=5^{\circ} \mathrm{C}$;

- overheating of the refrigerant vapor in the evaporator $\Delta t_{\text {overheat }}=10^{\circ} \mathrm{C}$;

- final temperature difference in the evaporator (internal air and boiled refrigeration agent) $\Delta t_{\mathfrak{e v}}=2.8^{\circ} \mathrm{C}$

- final temperature difference in the condenser (external air and condensing refrigerant) $\Delta t_{\text {cond }}=4.2^{\circ} \mathrm{C}$.

For calculations on the computer mathematical model the $(p, i)$-diagram of the refrigerants $\mathrm{R} 410 \mathrm{~A}$, R32 and R600A in the temperature range $0 \ldots 50^{\circ} \mathrm{C}$ was fed as analytical dependences $p=f(t)$, $i=\varphi(t), s=\psi(t)$.

The calculation results are summarized in Table 1. 
Table 1. Results of calculating of exergetic OIR and losses of exergy in the air split-conditioner elements with nominal cooling capacity $2800 \mathrm{~W}$ of firm "Daikin".

\begin{tabular}{|c|c|c|c|c|c|}
\hline \multirow{2}{*}{$\begin{array}{c}\text { Refrigeration } \\
\text { agent }\end{array}$} & \multicolumn{4}{|c|}{ Losses of exergy in the air split-conditioner elements, \% } & Exergetic OIR \\
\cline { 2 - 5 } & $D_{\text {compr }}$ & $D_{\text {cond }}$ & $D_{\text {thr }}$ & $D_{\text {ev }}^{\text {irrev.h.tr }}$ & $\eta_{\mathrm{e}}, \%$ \\
\hline R410A & 26.9 & 20.4 & 10.7 & 18.5 & 23.4 \\
\hline R32 & 27.1 & 21.5 & 4.9 & 22.2 & 24.2 \\
\hline R600A & 27.0 & 20.0 & 5.9 & 20.8 & 26.3 \\
\hline
\end{tabular}

The growth of the exergetic OIR due to transition from the refrigerants R410A and R32, respectively, to the refrigerant R600A, which proposed by the authors for use in split-conditioners, is:

$$
\begin{aligned}
& \Delta_{R 600 A}=\frac{26.3-23.4}{23.4} \cdot 100=12.4 \% \\
& \Delta_{R 600 A}=\frac{26.3-24.2}{24.2} \cdot 100=8.7 \% .
\end{aligned}
$$

According to the results of calculation, the Grassmann's diagram of the exergetic flows of the refrigerating machine of the air split-conditioner have been built (Fig. 2).

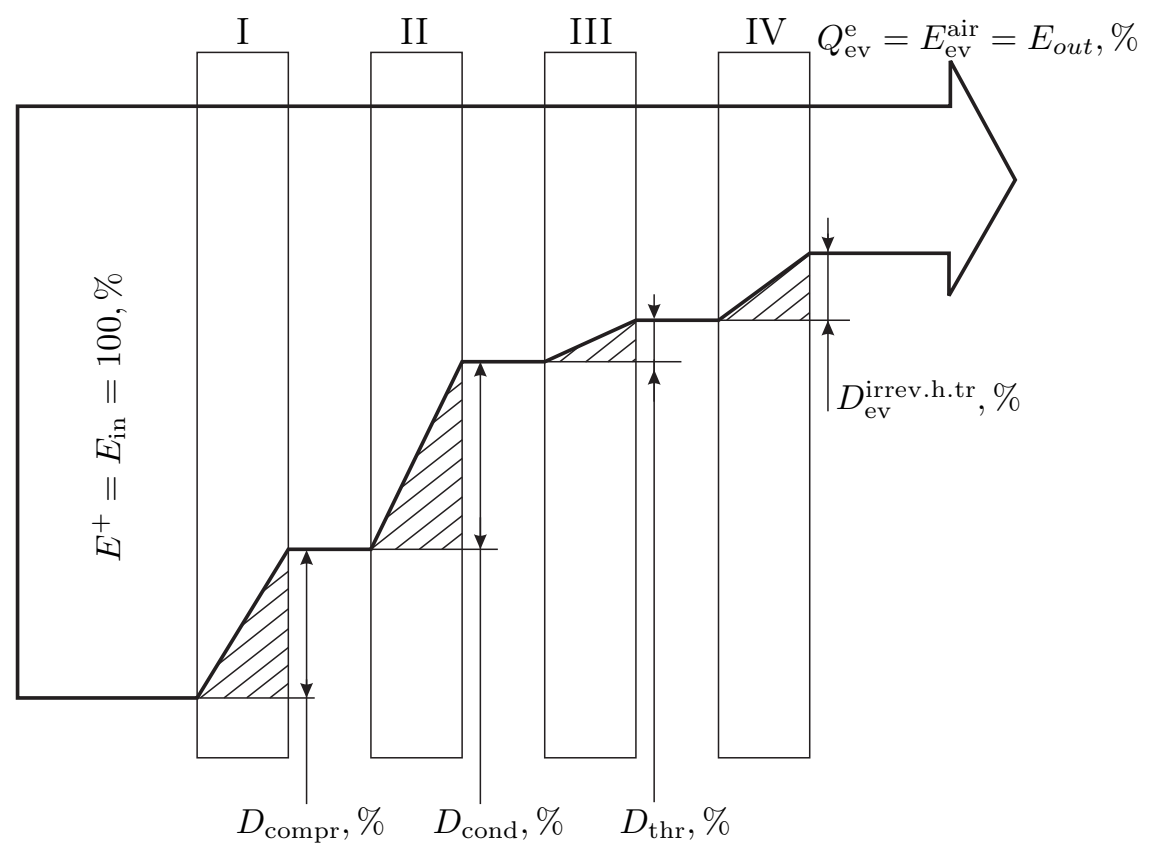

Fig. 2. The Grassmann's diagram of the exergetic flows of the refrigerating machine of the air split-conditioner: $D_{\text {compr }}, D_{\text {cond }}, D_{\mathrm{thr}}, D_{\mathrm{ev}}^{\text {irrev.h.tr }}$ are respectively, losses of exergy in the compressor, the condenser, the capillary tube and the evaporator, $\%$.

\section{Conclusions}

The author's innovative mathematical model for exergetic analysis of the operation of one-stage refrigerating machines, used in local autonomous air conditioners, has been developed. The experiments having been conducted on the the basis of the mathematical model establish the exergetic OIR and losses of exergy in separate air split-conditioner elements with a nominal cooling capacity $2800 \mathrm{~W}$ of "Daikin" under standard external temperature conditions for refrigerants R410A, R32 and at R600A which was proposed by the authors for the use in split-conditioners. 
Due to this, it can be asserted that the refrigerant R600A is the most effective among the exergetic OIR. It has been determined that the use of the R600A refrigerant in comparison with R410A and R32 will increase the exergetic efficiency of the split-conditioner in $12.4 \%$ and $8.7 \%$, respectively. The losses of exergy having been revealed in all elements of the air split-conditioner indicate the fact that elements of the air split-conditioner must be improved for reducing losses of exergy in them and the overall increase of exergetic OIR.

This mathematical model of operation of the split-conditioner can be applied to different types of refrigerants and split-conditioner models provided the thermodynamic properties of the refrigerant and the characteristics of the split-conditioner are known.

[1] Szargut J., Petela R. Exergy. Moscow, Energy (1968), (in Russian).

[2] Sokolov E. Y., Brodyansky V. M. Energy Basis of Transformation of Heat and Cooling Processes. Moscow, Energoizdat (1981), (in Russian).

[3] de Oliveira Junior S. Exergy. - Production, Cost and Renewability. London, Springer-Verlag (2013).

[4] Sazhin B. S., Bulekov B.S., Sazhin B.S. Exergy Analysis of Work of Industrial Plants): Monograph. Moscow (2000), (in Russian).

[5] Bejan A. Advanced Engineering Thermodynamics. New York, John Wiley \& Sons (1988).

[6] Bejan A., Tsatsaronis G., Moran M. Thermal Design and Optimization. New York, J. Wiley (1996).

[7] Morosuk T., Nikulshin R., Morosuk L. Entropy-Cycle Method for Analysis of Refrigeration Machine and Heat Pump Cycles. Thermal science. 10 (1), 111-124 (2006).

[8] Morozyuk T. V. Theory of Refrigeration Machines and Heat Pumps. Odessa, Studio "Negotsiant" (2006), (in Russian).

[9] Morozyuk L. I., Morozyuk T. V., Gaiduk S. V. Thermodynamic Analysis of Waste Heat Recovery Refrigeration Machine with Carbon Dioxide. Eastern-European Journal of Enterprise Technologies. 2/8 (68), 36-44 (2014), (in Russian).

[10] Tsatsaronis J. The Interaction of Thermodynamics and Economy to Minimize Cost of Energy Conversion Systems. Odessa, Studio "Negotsiant" (2002), (in Russian).

[11] Labay V. Yo., Khanyk Ya. M. Used in Air Split-conditioners Refrigerants R407C and R410A. Scientific and Technical Journal "Refrigeration Engineering and Technology". 3 (113), 13-17 (2008), (in Ukrainian).

[12] Labay V. Yo., Khanyk Ya. M. Energy Saving Ratio Between the Air Flows at the Evaporator and Condenser Air Split-conditioners. Scientific and Technical Journal "Refrigeration Engineering and Technology". 6 (116), 28-31 (2008), (in Ukrainian).

[13] Labay V. Yo., Mysak Yo. S. Adduction of Work of Refrigeration's Machines of Air Split-conditioners to the Identical Internal Temperature Condition. Scientific and Technical Journal "Refrigeration Engineering and Technology". 4 (126), 19-22 (2010), (in Ukrainian).

[14] Jakobsen A., Rassmussen B.-D., Skovrup M.-J., Andersen S.-E. CoolPack - a collection of simulation tools for refrigeration systemes. Tutorial, Version 1.46. Department of Energy Engineering Technical University of Denmark (2001).

[15] Daikin Catalog Split (2017). 


\title{
Математичне моделювання роботи спліт-кондиціонера для дослідження ексергетичної ефективності застосування холодоагента R600A
}

\author{
Лабай В., Довбуш О., Ярослав В., Клименко Г. \\ Кафедра теплогазопостачання $i$ вентиляиї, \\ Інститут будівництва та інженерії довкілля, \\ Націоналъний університет "Львівсъка політехніка", \\ вул. С. Бандери, 12, Лъвів, 79013, Україна
}

У сучасних технологіях, пов'язаних з перетворенням енергії, а саме в split-кондиціонерах, важливе місце займають апарати та процеси. Об'єктивно оцінити ступінь їх енергетичної досконалості можна лише на основі аналізу їх ексергетичної ефективності. Це дозволило обгрунтувати актуальність дослідницького завдання, що пов'язано із недостатньою інформацією щодо ефективності використання різних холодоагентів у спліт-кондиціонерах. Розроблено авторську інноваційну математичну модель для аналізу роботи одноступеневих фреонових холодильних машин, які використовують у split-кондиціонерах, за ексергетичним методом. На цій моделі отримано ексергетичний коефіцієнт корисної дії (ККД) та втрати ексергії в окремих елементаx split-кондиціонера на прикладі кондиціонера з номінальною холодопродуктивністю 2800 Вт фірми "Daikin" за стандартних зовнішніх температурних умов на холодоагентах R410A, R32 i запропонованого авторами для використання y splitкондиціонерах холодоагента R600A. Виявлено, що за ексергетичним КKД холодильний агент R600A є найефективнішим. Використання холодоагента R600A порівняно з R410A i R32 показало збільшення ексергетичної ефективності split-кондиціонера на $12.4 \%$ і $8.7 \%$, відповідно. Втрати ексергії, виявлені в усіх елементах холодильної машини split-кондиціонера, вказують на необхідність удосконалення обладнання split-кондиціонера, щоб зменшити втрати ексергії в них та загалом збільшити його ексергетичний ККД.

Ключові слова: split-кондичіонер, ексергетичний баланс, ексергетичний ККД, втрати ексергї, холодоагент.

2000 MSC: $80 \mathrm{~A} 10,80 \mathrm{~A} 20$

УдК: 697.94.(075) 